Rev. Fac. Agron. (LUZ). 2021, 38(4): 806-824. Octubre-Diciembre.

DOI: https://doi.org/10.47280/RevFacAgron(LUZ).v38.n4.04

ISSN 2477-9407

\title{
Foliar fertilization of sodium selenite and its effects on yield and nutraceutical quality in grapevine
}

\author{
Fertilización foliar con selenito de sodio y su efecto sobre \\ el rendimiento y calidad nutracéutica en el cultivo de vid
}

\section{Fertilização foliar com selenita de sódio e seu efeito sobre o rendimento e qualidade nutracêutica no cultivo de videiras}

\begin{abstract}
María de los Ángeles Sariñana-Navarrete ${ }^{1}$, Luis Guillermo Hernández-

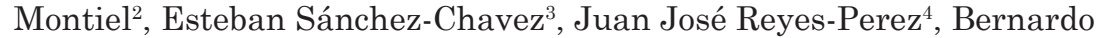
Murillo-Amador ${ }^{2}$, Arturo Reyes-González ${ }^{5}$, Pablo Preciado-Rangel ${ }^{1^{*}}$
\end{abstract}

\begin{abstract}
${ }^{1}$ Tecnológico Nacional de México/ Instituto Tecnológico de Torreón. Carretera Torreón-San Pedro km 7.5, Ejido Ana. Torreón, Coahuila, 27170, México. Correos electrónicos: (MA) est_primo23@hotmail.com; (D; (PP) ppreciador@yahoo.com.mx; (iD. ${ }^{2}$ Centro de Investigaciones Biológicas del Noroeste. Av. Instituto Politécnico Nacional 195, Col. Playa Palo de Santa Rita, La Paz, Baja California Sur, 23096, México. Correos electrónicos: (LG) hernandez@cibnor.mx; (D); (BM) bmurillo04@ cibnor.mx; (D. ${ }^{3}$ Centro de Investigación en Alimentación y Desarrollo, A.C. Unidad Delicias, Avenida Cuarta Sur No. 3820 Fraccionamiento Vencedores del Desierto, Delicias, Chihuahua, México Chihuahua, México. Correos electrónico: (ES) esteban@ ciad.mx (D. ${ }^{4}$ Universidad Técnica Estatal de Quevedo. Av. Quito. Km 1 1/2 vía a Santo Domingo. Quevedo, Los Ríos, Ecuador. Correos electrónico: (JJ) jreyes@uteq.edu.ec; (D. ${ }^{5}$ Instituto Nacional de Investigaciones Forestales, Agrícolas y Pecuarias. Blvd. José Santos Valdez No- 1200 pte. Matamoros, Coahuila, 27440, México. Correos electrónico: (AG) reyes.arturo@inifap.gob.mx; (D.
\end{abstract}

\section{Abstract}

Selenium (Se) is an essential micronutrient for humans, but in plants, this essentiality has not been demonstrated. However, the supplementation of Se in crops has been shown to improve the yield and the quality of the edible part. The objective of this research was to evaluate the effect of Se foliar fertilization on yield, nutraceutical quality and Se accumulation in grape. Five doses of Se $\left(\mathrm{Na}_{2} \mathrm{SeO}_{3}\right.$ at $0.25,0.5,0.75,1.0$ and $\left.1.25 \mathrm{mg} . \mathrm{L}^{-1}\right)$ and a control were evaluated.

Received: 16-11-2020 • Accepted: 01-02-2021.

*Corresponding autor. Email: ppreciador@yahoo.com.mx 
The results obtained showed that the application in low doses of Se increased the yield; high doses increase nutraceutical quality and induced the accumulation of Se in grapes. In conclusion, the grapevine is a crop with the potential to be biofortified and improve the quality of grape.

Keywords: Vitis vinifera; plant nutrition; selenium; phytochemical compounds.

\section{Resumen}

El selenio (Se) es un micronutriente esencial para el ser humano, pero en las plantas, esta esencialidad no se ha demostrado. Sin embargo, la suplementación de Se en los cultivos ha demostrado mejorar el rendimiento, y la calidad de la parte comestible. El objetivo de esta investigación fue evaluar el efecto de la fertilización foliar de Se sobre el rendimiento, calidad nutracéutica y la acumulación de Se en bayas de uva. Se evaluaron cinco dosis de $\mathrm{Se}\left(\mathrm{Na}_{2} \mathrm{SeO}_{3}\right.$ a 0,$25 ; 0,5 ; 0,75 ; 1,0$ y 1,25 mg. $\mathrm{L}^{-1}$ ) y un control. Los resultados obtenidos mostraron que la aplicación en dosis bajas de Se incrementó el rendimiento; en contraste dosis altas mejoran la calidad nutracéutica e inducen la acumulación de Se en las uvas. En conclusión, la vid es un cultivo con potencial de ser biofortificado y mejorar calidad de las bayas de uva.

Palabras clave: Vitis vinifera; nutrición de las plantas; selenio; compuestos fitoquímicos.

\section{Resumo}

O selênio (Se) é um micronutriente essencial para humanos, mas em plantas essa essencialidade não foi demonstrada. No entanto, a suplementação de Se nas lavouras tem mostrado melhorar o rendimento e a qualidade da parte comestível. O objetivo desta pesquisa foi avaliar o efeito da adubação foliar com Se na produtividade, qualidade nutracêutica e acúmulo de Se em bagos de uva. Foram avaliadas cinco doses de $\mathrm{Se}\left(\mathrm{Na}_{2} \mathrm{SeO}_{3}\right.$ a 0,$25 ; 0,5 ; 0,75 ; 1,0$ y $\left.1,25 \mathrm{mg} \cdot \mathrm{L}^{-1}\right)$ e um controle. Os resultados mostraram que a aplicação de baixa dose de aumento de desempenho; Em contrapartida, altas doses melhoram a qualidade nutracêutica e induzem o acúmulo de se em uvas. Em conclusão, a videira é uma cultura com potencial para ser bioesperificada e melhorar a qualidade das frutas de uva.

Palavras-chave: Vitis vinifera; nutrição de plantas; selênio; compostos fitoquímicos.

\section{Introduction}

Selenium (Se) is an important mineral in human nutrition and is essential to form vital proteins and enzymes such as glutathione

\section{Introducción}

El selenio (Se) es un mineral importante en la nutrición humana y es esencial para formar proteínas y enzimas vitales tales como: glutatión 
Rev. Fac. Agron. (LUZ). 2021, 38(4):806-824. Octubre-Diciembre.

\section{Sariñana-Navarrete et al.}

ISSN 2477-9407

peroxidase, thyroxine 5-deiodinase and selenoprotein. It also has antioxidant properties and protects against free radicals and various carcinogenic factors (Ducsay et al., 2016). According to the World Health Organization, Se consumption in the human diet should be between 55 to $200 \mu$ day $^{-1}$ per adult (WHO, 2009). The most common way in which the human organism acquires Se is by consumption of foods, such as meat or fish (Willers et al., 2015). In the world, there is one billion people with Se deficiencies, due to the consumption of primarily plant-based diets (Wu et al., 2015); plants contain low concentrations of Se, because this mineral is found in small quantities in the soil (Ponavic and Scheib, 2014). Biofortification increases the absorption and accumulation of specific nutrients, e.g., Se, in agricultural food products through plant breeding, genetic engineering and synthetic fertilization (Bocchini et al., 2018). In recent years, studies on the biofortification have increased Se concentration in plants offering the potential to increase Se intake by humans through the consumption of agricultural crops (Mora et al., 2015). Foliar fertilization to agricultural crops is an alternative for incorporating Se into the food chain. Although Se is not considered essential to plants, it has been shown that at low concentrations Se increases crop growth, yield and antioxidant content (Gaucín-Delgado et al., 2020) and its concentration in the edible part (Kuldeep et al., 2010). One of the ways of applying Se to plants is through application of peroxidasa, tiroxina 5-deiodinasa y selenoproteína. También posee propiedades antioxidantes y protege contra los radicales libres y diversos factores carcinógenos (Ducsay et al., 2016). De acuerdo a la Organización Mundial de la Salud, el consumo de Se en la dieta humana debe estar entre 55 a $200 \mu \mathrm{g}$ día $^{-1}$ por adulto (WHO, 2009). La forma más común por la cual el organismo humano adquiere el Se es a través del consumo de alimentos, tales como la carne o el pescado (Willers et al., 2015). En el mundo, existen mil millones de personas con deficiencias de Se, debido al consumo de dietas basadas en vegetales principalmente (Wu et al., 2015); las plantas contienen bajas concentraciones de Se, ya que este mineral se encuentra en pequeñas cantidades en el suelo (Ponavic y Scheib, 2014). La biofortificación aumenta la absorción y la acumulación de nutrientes específicos como por ejemplo, el Se en los productos alimentarios agrícolas a través del fitomejoramiento, ingeniería genética y fertilización sintética (Bocchini et al., 2018). En los últimos años, los estudios sobre la biofortificación han incrementado la concentración de Se en las plantas, ofreciendo el potencial de aumentar la ingesta de Se por parte de los seres humanos a través del consumo de cultivos agrícolas (Mora et al., 2015). La fertilización foliar para los cultivos agrícolas es una alternativa para incorporar el Se a la cadena alimenticia. Aunque el Se no se considera esencial para las plantas, se ha demostrado que a bajas concentraciones el Se aumenta el crecimiento del cultivo, el rendimiento 
sodium selenite $\left(\mathrm{Na}_{2} \mathrm{SeO}_{3}\right)$. Sodium selenite is effective, safe, and has proven to be more bioavailable to plants when applied directly to foliage than when incorporated into the soil (Kápolna et al., 2009). The grape (Vitis vinifera L.), is considered to be a functional food because it contains glucose and fructose and has a high amount of phenolic compounds that have pharmacological, antimicrobial and antioxidant properties (Aviña de la Rosa et al., 2016); contains vitamins $\mathrm{A}, \mathrm{C}, \mathrm{E}, \mathrm{B} 1, \mathrm{~B} 3, \mathrm{~B} 6$ and $\mathrm{B} 9$, and minerals such as $\mathrm{Ca}, \mathrm{P}, \mathrm{Na}, \mathrm{K}$, $\mathrm{Fe}, \mathrm{Cu}, \mathrm{Mg}$, and $\mathrm{Zn}$. The shell and seed of grape contain polyphenols, vitamins $\mathrm{C}, \mathrm{E}$ and flavonoids that provide protection against oxidative stress in human (Molina-Quijada et al., 2010). Therefore, the objective of this study was the biofortification with Se in grapevine, and to evaluate its impact on the performance parameters, nutraceutical quality and the accumulation of Se in fruit.

\section{Materials and methods}

\section{Study area}

The experiment was carried out in 2018 in a commercial orchard located in Monterrey, Durango, Mexico at $25^{\circ} 29^{\prime} 20^{\prime \prime} \mathrm{N}, 103^{\circ} 37^{\prime} 37^{\prime} \mathrm{W}$. The climate of study area is dry steppe; average temperature of $21^{\circ} \mathrm{C}$ and annual rainfall of $253 \mathrm{~mm}$. The soil texture is sandy loam ( $81 \%$ sand, $14 \%$ silt and

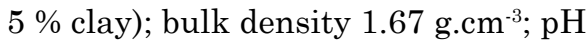
of 8.37 ; water retention capacity of $25.2 \%$; electrical conductivity of 1.28 dS.m ${ }^{-1}$; organic matter content 1.18 mg.kg-1 ${ }^{-1}$ total nitrogen of $32.8 \mathrm{mg} . \mathrm{kg}^{-1}$; y el contenido antioxidante (Gaucín-Delgado et al., 2020) y su concentración en la parte comestible (Kuldeep et al., 2010). Unas de las formas de aplicar el Se a las plantas es mediante la aplicación de selenito de sodio $\left(\mathrm{Na}_{2} \mathrm{SeO}_{3}\right)$. El selenito de sodio es eficaz, seguro y ha demostrado ser más biodisponible para las plantas cuando se aplica directamente al follaje que cuando se incorpora al suelo (Kápolna et al., 2009). La vid (Vitis vinifera L.) se considera un alimento funcional ya que contiene glucosa y fructuosa y tiene una alta cantidad de compuestos fenólicos que tienen propiedades farmacológicas, antimicrobianas y antioxidantes (Aviña de la Rosa et al., 2016); contiene vitaminas A, C, E, B1, B3, B6 y B9, y minerales tales como $\mathrm{Ca}, \mathrm{P}, \mathrm{Na}, \mathrm{K}, \mathrm{Fe}, \mathrm{Cu}, \mathrm{Mg}$, y Zn. La cáscara y la semilla de la uva contienen polifenoles, vitaminas $\mathrm{C}, \mathrm{E}$ y flavonoides que proporcionan protección contra el estrés oxidativo en el ser humano (Molina-Quijada et al., 2010). Por lo tanto, el objetivo de este estudio fue la biofortificación con Se en la vid, y evaluar su impacto en los parámetros de rendimiento, la calidad nutracéutica y la acumulación de Se en el fruto.

\section{Materiales y métodos}

\section{Área de estudio}

El experimento se llevó a cabo en el 2018, en un huerto comercial ubicado en Monterrey, Durango, México a $25^{\circ} 29^{\prime} 20^{\prime \prime} \mathrm{N}, 103^{\circ} 37^{\prime} 37^{\prime} \mathrm{W}$. El clima del área de estudio es de estepa seca; temperatura promedio de $21^{\circ} \mathrm{C}$ y una precipitación anual de $253 \mathrm{~mm}$. La 
Rev. Fac. Agron. (LUZ). 2021, 38(4):806-824. Octubre-Diciembre.

\section{Sariñana-Navarrete et $a l$.}

ISSN 2477-9407

available phosphorus of $24.4 \mathrm{mg} \cdot \mathrm{kg}^{-1}$ and removable potassium of 90.43 mg.kg-1.

\section{Plantation}

Grape "Cabernet Sauvignon" plants of 7 years old were used. The planting system was $1 \mathrm{~m}$ between plants and $3 \mathrm{~m}$ between rows, with a plant density 3,333 plant.ha ${ }^{-1}$.

Selenite doses and application on grape plants

The sodium selenite $\left(\mathrm{Na}_{2} \mathrm{SeO}_{3}, 95 \%\right.$ purity, Sigma-Aldrich ${ }^{\circledR}$ ) was prepared at $0.25,0.5,0.75,1.0$ and 1.25 mg.L ${ }^{-1}$ using distilled water, and a non-toxic commercial surfactant (INEX-A ${ }^{\circledR}, 2$ $\left.\mathrm{mL} . \mathrm{L}^{-1}\right)$. Sodium selenite solutions were applied (200 $\mathrm{mL}$ per plant) by foliar sprays using a manual sprinkler backpack (Truper $\left.{ }^{\circledR}\right)$. Applications were conducted in the morning (at sunrise), during fruit formation, veraison, and 15 days before harvest. The control plants ( 0 mg. $\mathrm{L}^{-1} \mathrm{Na}_{2} \mathrm{SeO}_{3}$ ) received only $200 \mathrm{~mL}$ per plant of distilled water. Each experimental plot consisted of 10 plants. The experiment was repeated twice.

\section{Yield and quality of grapes}

Fruit yield, and bunches weight was measured in 10 plants per treatment. Fruit total soluble solids (TSS) and titratable acidity (TA) were determined in the juice of 50 fruit per treatment. TSS was measured with manual refractometer 0-32 \% (Sper Scientific $^{\circledR}$ 30001, Sper Scientific LTD, Scottsdale Az, USA) and expressed in ${ }^{\circ}$ Brix. TA was determined following the methodology of AOAC (AOAC, 1990), using $\mathrm{NaOH}(0.1 \mathrm{~N})$ and phenolphthalein (1\%) as an indicator; results expressed as percentage of textura del suelo es franco arenosa (81\% arena, $14 \%$ limo y 5\% arcilla); densidad aparente 1,67 g.cm ${ }^{-3} ; \mathrm{pH}$ de 8,37; capacidad de retención de agua del 25,2\%; conductividad eléctrica de $1,28 \mathrm{dS} \cdot \mathrm{m}^{-1}$; contenido de materia orgánica $1,18 \mathrm{mg} \cdot \mathrm{kg}^{-1}$; nitrógeno total de $32,8 \mathrm{mg} \cdot \mathrm{kg}^{-1}$; fósforo disponible de $24,4 \mathrm{mg} \cdot \mathrm{kg}^{-1}$ y potasio removible de 90,43 mg.kg-1.

\section{Plantación}

Se utilizaron las plantas de vid "Cabernet Sauvignon" de 7 años de edad. El sistema de plantación fue de $1 \mathrm{~m}$ entre plantas y $3 \mathrm{~m}$ entre hileras, con una densidad de planta de 3.333 planta.ha ${ }^{-1}$.

Dosis de selenito y aplicación en las plantas de vid

El selenito de sodio $\left(\mathrm{Na}_{2} \mathrm{SeO}_{3}\right.$, $95 \%$ de pureza, Sigma-Aldrich $\left.{ }^{\circledR}\right)$ se preparó a 0,$25 ; 0,5 ; 0,75 ; 1,0$ y 1,25 mg. $\mathrm{L}^{-1}$ utilizando agua destilada, y un surfactante comercial no tóxico (INEX-A ${ }^{\circledR}, 2$ mL.L ${ }^{-1}$ ). Las soluciones de selenito de sodio se aplicaron (200 $\mathrm{mL}$ por planta) por aspersión foliar utilizando una mochila de aspersión manual (Truper®). Las aplicaciones se realizaron por la mañana (al amanecer), durante la formación del fruto, en envero y 15 días antes de la cosecha. Las plantas de control (0 mg.L. $\mathrm{L}^{-1}$ de $\mathrm{Na}_{2} \mathrm{SeO}_{3}$ ) recibieron sólo 200 $\mathrm{mL}$ por planta de agua destilada. Cada parcela experimental constaba de 10 plantas. El experimento se repitió dos veces.

Rendimiento y calidad de las uvas

Se midió el rendimiento de los frutos, y el peso de los racimos en 10 plantas por tratamiento. Se 
Rev. Fac. Agron. (LUZ). 2021, 38(4):806-824. Octubre-Diciembre.

Sariñana-Navarrete et al.

ISSN 2477-9407

tartaric acid per 100 g. Fruit volume was determined by water displacement in 50 fruit per treatment. Maturity index (MI) was calculated with the relationship TSS/TA.

\section{Nutraceutical fruit quality}

\section{Polyphenol content}

Total phenolic content was determined using a Folin-Ciocalteau method (Garcia-Nava, 2009). Samples were quantified in an ultraviolet (UV)-Vis spectrophotometer at 760 nm (master spectrum FISHER SCIENTIFIC 415). The standard was prepared with gallic acid. Results were expressed in mg GAE.100 $\mathrm{g}^{-1}$ fresh weight (FW).

\section{Flavonoids content}

Total flavonoids were determined by colorimetry (García-Nava, 2009). Samples were quantified in a UV-Vis spectrophotometer at $510 \mathrm{~nm}$ (master spectrum Fisher Scientific 415). The standard was prepared with quercetin dissolved in absolute ethanol ( $\mathrm{y}=$ 0.0122x-0.0067; $\left.R^{2}=0.965\right)$. Results were expressed in mg QE.100 g-1 $\mathrm{FW}$.

\section{Antioxidant capacity}

Total antioxidant capacity was measured by the in-vitro $\mathrm{DPPH}^{+}$ method (Brand-Williams et al., 1995). Samples were quantified in a UV-Vis spectrophotometer at $517 \mathrm{~nm}$ (master spectrum Fisher Scientific 415). The standard was prepared with Trolox (0.1-1.0 mM, $\mathrm{R}^{2}=$ 0.998). Results were expressed in $\mu \mathrm{M}$ equivalent in Trolox. $100 \mathrm{~g}^{-1} \mathrm{FW}$.

\section{Selenium accumulation in fruits \\ The Se concentration in fruits was determined by atomic absorption}

determinaron los sólidos solubles totales de la fruta (SST) y la acidez titulable (AT) en el zumo de 50 frutas por tratamiento. Los SST se midieron con un refractómetro manual 0-32 \% (Sper Scientific ${ }^{\circledR}$ 30001, Sper Scientific LTD, Scottsdale Az, USA) y se expresaron en ${ }^{\circ}$ Brix. La AT se determinó siguiendo la metodología de AOAC (AOAC, 1990), usando $\mathrm{NaOH}(0,1 \mathrm{~N})$ y fenolftaleína (1\%) como indicador; los resultados se expresaron como porcentaje de ácido tartárico por 100 g. El volumen de los frutos se determinó por desplazamiento de agua en 50 frutos por tratamiento. El índice de madurez (IM) se calculó con la relación SST/TA.

\section{Calidad nutracéutica del fruto \\ Contenido de polifenoles}

El contenido fenólico total se determinó mediante el método de Folin-Ciocalteau

(García-Nava, 2009). Las muestras se cuantificaron en un espectrofotómetro ultravioleta (UV)-Vis a $760 \mathrm{~nm}$ (master spectrum FISHER SCIENTIFIC 415). El estándar se preparó con ácido gálico. Los resultados se expresaron en $\mathrm{mg}$ GAE. $100 \mathrm{~g}^{-1}$ peso fresco (PF).

\section{Contenido de flavonoides}

Se determinaron los flavonoides totales por colorimetría (GarcíaNava, 2009). Las muestras se cuantificaron en un Espectrofotómetro UV-Vis a $510 \mathrm{~nm}$ (master spectrum Fisher Scientific 415). El estándar se preparó con quercetina disuelta en etanol absoluto ( $\mathrm{y}=0,0122 \mathrm{x}-0,0067 ; \mathrm{R}^{2}=$ 0,965). Los resultados se expresaron en mg QE.100 g-1 PF. 
Rev. Fac. Agron. (LUZ). 2021, 38(4):806-824. Octubre-Diciembre.

spectrophotometry (Varian SpectrAA, modelo 220Fast) using the methodology reported by Silva-Trejos, (2011). Fifty fruits per treatment were used and the results were expressed in $\mu$ g.kg ${ }^{-1}$ dry weight (DW).

\section{Statistical analysis}

Data were analyzed by a one-way analysis of variance (ANOVA) and Tukey's HSD multiple range test with a significance level of $5 \%$, using Statistica v. 10.0 (StatSoft, 2011).

\section{Results and discussions}

\section{Yield and quality of grapes}

The foliar application of different doses of sodium selenite to grapevine affected the fruit yield per plant, bunches weight, titratable acidity and grape volume (Table 1).

\section{Capacidad antioxidante}

La capacidad antioxidante total se midió por el método in vitro de DPPH+ (Brand-Williams et al., 1995). Las muestras se cuantificaron en un espectrofotómetro UV-Vis a $517 \mathrm{~nm}$ (master spectrum Fisher Scientific 415). El estándar se preparó con Trolox (0,1-1,0 mM, $\left.\mathrm{r}^{2}=0,998\right)$. Los resultados se expresaron en $\mu \mathrm{M}$ equivalente en Trolox. $100 \mathrm{~g}^{-1} \mathrm{PF}$.

Acumulación de selenio en los frutos

La concentración de Se en los frutos se determinó por espectrofotometría de absorción atómica (Varian SpectrAA, modelo 220Fast) utilizando la metodología reportada por SilvaTrejos, (2011). Se usaron cincuenta frutos por tratamiento y los resultados se expresaron en $\mu \mathrm{g} \cdot \mathrm{kg}^{-1}$ peso seco (PS).

Table 1. Effect of doses of sodium selenite applied foliar on fruit yield, total soluble solids (TSS), titratable acidity (TA), and fruit volume in grape 'Cabernet Sauvignon' var.

Cuadro 1. Efecto de las dosis de selenito de sodio aplicadas por vía foliar sobre el rendimiento del fruto, los sólidos solubles totales (SST), la acidez titulable (AT) y el volumen del fruto en la uva var 'Cabernet Sauvignon'.

\begin{tabular}{ccccccc}
\hline $\mathbf{N a}_{2} \mathbf{S e O}_{3}\left(\mathbf{m g} . L^{-1}\right)$ & $\begin{array}{c}\text { Fruit yield. } \\
\text { plant }^{-\mathbf{1}} \mathbf{( k g )}\end{array}$ & $\begin{array}{c}\text { Bunches } \\
\text { weight (g) }\end{array}$ & $\begin{array}{c}\text { TSS } \\
{ }^{\circ} \text { Brix) }\end{array}$ & $\begin{array}{c}\text { TA } \\
(\%)\end{array}$ & $\begin{array}{c}\text { Maturity } \\
\text { index }\end{array}$ & $\begin{array}{c}\text { Fruit } \\
\text { volume (cc) }\end{array}$ \\
\hline $\mathbf{0 . 2 5}$ & $2.18^{\mathrm{a}}$ & $77.74^{\mathrm{ab}}$ & $22.0^{\mathrm{a}}$ & $6.84^{\mathrm{a}}$ & $3.21^{\mathrm{a}}$ & $1.11^{\mathrm{d}}$ \\
$\mathbf{0 . 5 0}$ & $2.34^{\mathrm{a}}$ & $76.26^{\mathrm{ab}}$ & $22.3^{\mathrm{a}}$ & $6.59^{\mathrm{b}}$ & $3.39^{\mathrm{ab}}$ & $1.17^{\mathrm{cd}}$ \\
$\mathbf{0 . 7 5}$ & $1.25^{\mathrm{ab}}$ & $58.14^{\mathrm{c}}$ & $22.7^{\mathrm{a}}$ & $6.60^{\mathrm{b}}$ & $3.43^{\mathrm{ab}}$ & $1.26^{\mathrm{c}}$ \\
$\mathbf{1 . 0 0}$ & $1.24^{\mathrm{ab}}$ & $61.80^{\mathrm{bc}}$ & $22.3^{\mathrm{a}}$ & $6.61^{\mathrm{b}}$ & $3.37^{\mathrm{ab}}$ & $1.45^{\mathrm{b}}$ \\
$\mathbf{1 . 2 5}$ & $0.76^{\mathrm{b}}$ & $58.34^{\mathrm{bc}}$ & $23.0^{\mathrm{a}}$ & $6.60^{\mathrm{b}}$ & $3.48^{\mathrm{b}}$ & $1.62^{\mathrm{a}}$ \\
$\mathbf{C o n t r o l}$ & $2.17^{\mathrm{a}}$ & $80.96^{\mathrm{a}}$ & $22.3^{\mathrm{a}}$ & $6.77^{\mathrm{a}}$ & $3.30^{\mathrm{ab}}$ & $1.07^{\mathrm{d}}$ \\
\hline
\end{tabular}

a, b, c, d: Different letters indicate significant difference $(\mathrm{p}<0.05)$ according to Tukey's HSD test. a, b, c, d: Different letters indicate significant difference $(\mathrm{p}<0.05)$ according to Tukey's HSD test. 
Yield and bunch weight decrease 27.17 and 64.49 respectively; instead, the grape volume increased $51 \%$. The TSS did not show differences among treatments. The treatments with 0.25 and $1.25 \mathrm{mg} . \mathrm{L}^{-1}$ of sodium selenite increased maturity index between 3.21 and 3.48 in the grape. In species such as lettuce, potato and tomato, highlight that the application of low doses of Se $(10 \mu \mathrm{M})$ had growth promoting effects, while higher concentrations induced symptoms of toxicity in plants (Schiavon et al., 2013). Se is not considered essential in plant metabolism; therefore, the addition of this element is not expected to change the crop yield (Broadley et al., 2006). However, other studies reported that the application of $\mathrm{Se}$ in low concentration causes positive effects on yield, biomass production, among other (Zhu et al., 2017). In contrast, high doses of Se cause toxicity in the plants because there is a high production of reactive oxygen species, found to inhibit growth and performance (Lapaz et al., 2019). The studies previously reported support our results that there is a decrease in grape production with higher concentrations of Se. Another study found a decrease of more than $21 \%$ in tomato crop yield with high doses of NPs-Se (Hernández-Hernández et al., 2019). In general, the response of the plant to Se differs according to the applied concentration (Puccinelli et al., 2017a), the sensitivity of the species (Lyons et al., 2005), the chemical species of Se used and the method of application; then, the optimal doses for each culture must be determined

\section{Análisis estadístico}

Los datos se analizaron mediante un análisis de varianza (ANOVA) de una vía y la prueba de rango múltiple HSD de Tukey con un nivel de significancia del $5 \%$, utilizando Statistica v. 10.0 (StatSoft, 2011).

\section{Resultados y discusión}

\section{Rendimiento y calidad de las uvas}

La aplicación foliar de diferentes dosis de selenito de sodio a la vid afectó al rendimiento de frutos por planta, el peso de los racimos, la acidez titulable y al volumen de la uva (Cuadro 1).

El rendimiento $\mathrm{y}$ el peso del racimo disminuyeron un 27,17 y un 64,49 respectivamente; en cambio el volumen de la uva aumentó un $51 \%$. El SST no mostró diferencias entre los tratamientos. Los tratamientos con 0,25 y 1,25 mg.L $\mathrm{L}^{-1}$ de selenito de sodio aumentaron el índice de madurez en la uva entre 3,21 y 3,48. En especies tales como la lechuga, la papa y el tomate se destaca que la aplicación de dosis bajas de Se $(10 \mu \mathrm{M})$ tuvo efectos promotores del crecimiento, mientras que a concentraciones más altas indujeron síntomas de toxicidad en las plantas (Schiavon et al., 2013). El Se no se considera esencial en el metabolismo de las plantas; por lo tanto, no se espera que la adición de este elemento modifique el rendimiento del cultivo (Broadley et al., 2006). Sin embargo, otros estudios reportaron que la aplicación de Se en bajas cantidades causa efectos positivos en el rendimiento, 
(Oliveira et al., 2018). In previous studies, Se enrichment can have a positive influence on fruit ripening and sugar metabolism. In fact, recent studies conducted on Camellia sinensis leaves have demonstrated a positive correlation between Se concentration and soluble sugars and the sweetness index (Zhao et al., 2016), suggesting that Se could play a role in acceleration ripening of fruit. Similarly, the rest of the Se doses did not produce any significant effect on TSS compared to the control; however, the TSS values were in the range of 20 to $26 \%$, similar to other reported results (Weaver, 1985). Other studies reported a relationship between TSS and TA (Zhu et al., 2017). Furthermore, a TA decrease was found in grapes treated with Se. The decrease in TA is attributed to malic acid, which is used as a substrate for the synthesis of sugars and for respiration during ripening (Ruffner, 1982). Variation in Se availability for plants has often been associated with impaired sulfur absorption, leading to changes in the synthesis of secondary metabolites (Malagoli et al., 2015). Walteros et al. (2012) discussed that the aromatic compounds and sugar/acid content are two elements important in the flavor of the grapes and that the maturity index between 3 and 3.5 suggest the commercial maturity of the fruit.

\section{Nutraceutical quality of grapes}

\section{Total phenolic, flavonoids and antioxidant capacity}

Phenols concentration in grape fruits increased as doses of sodium producción de biomasa, entre otros (Zhu et al., 2017). Por el contrario, altas dosis de Se causan toxicidad en las plantas ya que existe una alta producción de especies reactivas de oxígeno, que se han descubierto que inhiben el crecimiento y el rendimiento (Lapaz et al., 2019). Los estudios previamente reportados apoyan nuestros resultados sobre que existe una disminución en la producción de uva con mayores concentraciones de Se. Otro estudio encontró una disminución de más del $21 \%$ en el rendimiento del cultivo de tomate con altas dosis de NPs-Se (HernándezHernández et al., 2019). En general, la respuesta de la planta al Se difiere en función de la concentración aplicada (Puccinelli et al., 2017a), de la sensibilidad de las especies (Lyons et al., 2005), de la especies químicas de Se utilizadas y el método de aplicación; entonces, se deben determinar las dosis óptimas para cada cultivo (Oliveira et al., 2018). En estudios previos, el enriquecimiento con Se puede tener una influencia positiva en la maduración de la fruta y en el metabolismo de los azúcares. De hecho, estudios recientes realizados en hojas de Camellia sinensis han demostrado una correlación positiva entre la concentración de Se, los azúcares solubles y el índice de dulzor (Zhao et al., 2016), lo que sugiere que el Se podría desempeñar un papel en la aceleración de la maduración del fruto. Del mismo modo, el resto de las dosis de Se no produjeron ningún efecto significativo sobre el SST en comparación con el control; sin embargo, los valores de SST estuvieron 
Rev. Fac. Agron. (LUZ). 2021, 38(4):806-824. Octubre-Diciembre.

ISSN 2477-9407

selenite increased. Compared with control treatment, the phenols concentration increase of $98 \%$ when $1.25 \mathrm{mg} \cdot \mathrm{L}^{-1}$ of sodium selenite was applied (Figure 1A). High concentration of Se increased total flavonoids in grape fruits by $52 \%$ (Figure 1B). The foliar application of $1.25 \mathrm{mg} . \mathrm{L}^{-1}$ of Se increased the total antioxidant capacity in grape fruits by $44 \%$ (Figure 1C).
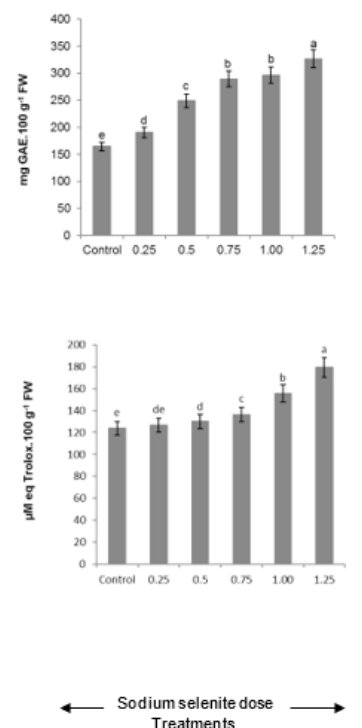

en el rango de 20 al $26 \%$, similar a otros resultados reportados (Weaver, 1985). Otros estudios informaron de una relación entre el SST y la AT (Zhu et al., 2017). Además, se encontró una disminución de la AT en las uvas tratadas con Se. La disminución de la AT se atribuye al ácido málico, que se utiliza como sustrato para la síntesis de azúcares y para la respiración durante la maduración
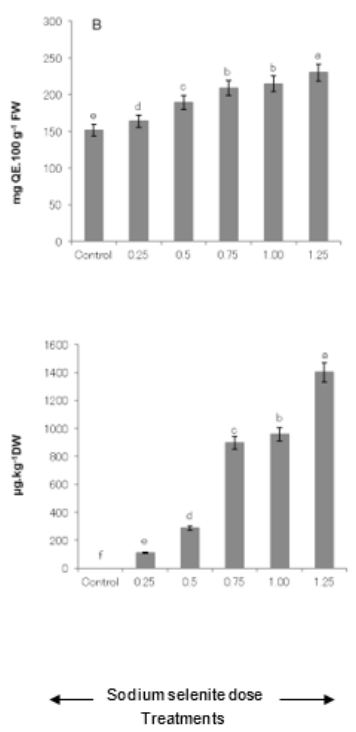

Figure 1. Effect of doses of sodium selenite on content of phenolic content (A), total flavonoids (B), antioxidant capacity (C), and Se concentration (D) in grape fruits. Data are shown as mean \pm standard deviation (SD) $(\boldsymbol{n}=\mathbf{5 0})$. Columns with different letters were significantly different according to Tukey's HSD test $(\mathrm{p}<0.05)$.

Figura 1. Efecto de las dosis de selenito de sodio sobre el contenido fenólico total (A), los flavonoides totales (B), la capacidad antioxidante (C), y la concentración de Se (D) en los frutos de uva. Los datos se muestran como media \pm desviación estándar (SD) $(n=50)$. Las columnas con letras diferentes fueron significativamente diferentes según la prueba HSD de Tukey $(\mathrm{p}<0,05)$. 
The biofortification significantly increases the amount of essential elements in the edible part of plant, which is consistent with what has been reported previously (GarduñoZepeda and Márquez-Quiroz, 2018). Several studies have also highlighted the contrasting effects of Se fertilization on the concentration of total phenols, either positive or negative, depending on the plant species and the Se concentration applied (Schiavon et al., 2013). In the case of grapes, the concentration of total phenolic compounds, flavonoids and antioxidant capacity was affected by the biofortification of Se. There is evidence that the cause is the positive regulation of the phenylpropanoid biosynthetic pathway which leads to the accumulation of specific metabolites that belong to a class of flavonoids and polyphenols (Mimmo et al., 2017), and play a central role in determining the organoleptic characteristics and antioxidant capacity of grapes.

Phenols are the third most abundant component in grapes, distributed mainly in the seeds and in the shell of the berries (Rousserie et al., 2019). Phenolic compounds, in addition to their astringent properties (Molina-Quijada et al., 2010), participate as natural antioxidants in food, characterizing themselves in functional foods (Porras-Loaiza and López-Malo, 2009). In grapes, whose final destination is wine production, the presence of these compounds determines the quality, since it gives them the oxidative capacity necessary to maintain the characteristic red color (Valls et al., 2000).
(Ruffner, 1982). La variación en la disponibilidad de Se para las plantas se ha asociado a menudo con la alteración de la absorción de azufre, lo que conduce a cambios en la síntesis de metabolitos secundarios (Malagoli et al., 2015). Walteros et al. (2012) discutieron que los compuestos aromáticos y el contenido de azúcar/ ácido son dos elementos importantes en el sabor de las uvas y que el índice de madurez entre 3 y 3,5 sugiere la madurez comercial de la fruta.

Calidad nutracéutica de las uvas

\section{Fenoles totales, flavonoides y capacidad antioxidante}

La concentración de fenoles en los frutos de uva aumentó a medida que se incrementaban las dosis de selenito de sodio. En comparación con el tratamiento de control, la concentración de fenoles aumentó un $98 \%$ cuando se aplicó 1,25 mg. $\mathrm{L}^{-1}$ de selenito de sodio (Figura 1A). La alta concentración de Se aumentó los flavonoides totales en los frutos de uva en un $52 \%$ (Figura 1B). La aplicación foliar de 1,25 mg. $\mathrm{L}^{-1}$ de Se aumentó la capacidad antioxidante total en los frutos de uva en un $44 \%$ (Figura $1 \mathrm{C}$ ).

La biofortificación aumenta significativamente la cantidad de elementos esenciales en la parte comestible de la planta, lo que coincide con lo reportado anteriormente (Garduño-Zepeda y Márquez-Quiroz, 2018). Varios estudios también han destacado que los efectos contrastados de la fertilización con Se sobre la concentración de los fenoles totales, positivos o negativos depende de las especies vegetales y de la concentración de Se aplicada (Schiavon et al., 2013). 
Studies support the increase in the content of phenolic compounds with the application of Se, reporting an increase of $8.07 \%$ in the total phenolic content in pomegranate fruits (Punica granatum) when performing foliar applications of 1 and $2 \mu \mathrm{M}$ Se and NPs-Se (Zahedi et al., 2019). In garlic (Allium sativum L.) a study found a positive response in the total phenolic content by foliar application of Se, with an increase of $82.23 \%$ compared to the control (Shafiq et al., 2019). Another study reported that the increase in phenolic compounds was showed with the application of stimulants during fruit veraison (Jeong et al., 2004). Although the context is not clearly defined, mechanisms of action of Se in plant metabolism have been proposed. One of them is through the biosynthetic pathway of organic compounds such as phenylpropanoid, which leads to the accumulation of secondary metabolites (Zahedi et al., 2019).

Flavonoids are bioactive compounds contained in all foods (Porras-Loaiza and López-Malo, 2009) and these groups of compounds are especially relevant in wine quality (Valls et al., 2000). Its structure gives them an antioxidant capacity, providing protection against oxidative damage in cells and also has a positive effect in a number of pathologies, including heart disease, atherosclerosis and cancer (MartínezFlórez et al., 2002). Regarding the total content of flavonoids, a study reveals that there is evidence of an effect of trace elements such as Se on the antioxidant capacity of plants
En el caso de las uvas, la concentración de los compuestos fenólicos totales, flavonoides $\mathrm{y}$ la capacidad antioxidante se vio afectada por la biofortificación de Se. Existen evidencias de que la causa es la regulación positiva de la vía biosintética de los fenilpropanoides que conduce a la acumulación de metabolitos específicos que pertenecen a una clase de flavonoides y polifenoles (Mimmo et al., 2017), y desempeñan un papel central en la determinación de las características organolépticas y la capacidad antioxidante de las uvas.

Los fenoles son el tercer componente más abundantes en la uva, distribuidos principalmente en las semillas y en la cáscara de las bayas (Rousserie et al., 2019). Los compuestos fenólicos, además de tener propiedades astringentes (MolinaQuijada et al., 2010), participan como antioxidantes naturales en los alimentos, caracterizándose en alimentos funcionales (Porras-Loaiza y López-Malo, 2009). En las uvas, cuyo destino final es la producción de vino, la presencia de estos compuestos determina la calidad, ya que les confiere la capacidad oxidativa necesaria para mantener el color rojo característico (Valls et al., 2000).

Los estudios apoyan el aumento en el contenido de compuestos fenólicos con la aplicación de Se, reportando un aumento de 8,07 \% en el contenido fenólico total en frutos de granada (Punica granatum) al realizar aplicaciones foliares de 1 y $2 \mu \mathrm{M}$ de Se y NPs-Se (Zahedi et al., 2019). En ajo (Allium sativum L.) un estudio encontró una respuesta positiva en el 
(Blasco et al., 2008). To explain this behavior, three synergistic transport mechanisms have been proposed in flavonoid biosynthesis, transport mediated by vesicle traffic, via membrane transporters, and transport mediated by the enzyme GlutathioneS-transferase (GST) (Rousserie et al., 2019). The latter, in turn, uses a cysteine residue (Cys), which is an amino acid where Se can replace sulfur, and form selenocysteine (Se-Cys) (Casals-Mercadal et al., 2005). Other studies aimed at increasing the total flavonoid content by the application of micronutrients have obtained favorable results. For example, a study reports a $63 \%$ increase in total flavonoids in garlic (Allium sativum L.) due to the application of Se (Shafiq et al., 2019).

The antioxidant capacity of fruits and vegetables is influenced by the total phenolic content (Franco-Bañuelos et al., 2019). In this research, a positive correlation $(r=0.82)$ was found between total antioxidant capacity and total phenolic compounds. Zahedi et al. (2019), reports an increase of $18.24 \%$ in the antioxidant capacity in pomegranate (Punica granatum) because of foliar application of Se. In the same way, an increase in the antioxidant capacity of tomato seeds and seedlings when Se was provide by nutrient solution and foliar spray was reported (de los Santos-Vázquez et al., 2016). Plant species contain a complex antioxidant defense network, where the most important compounds are ascorbate, glutathione, tannins, flavonoids and carotenoids, which provide protection against oxidative contenido fenólico total por aplicación foliar de Se, con un incremento del $82,23 \%$ respecto al control (Shafiq et al., 2019). Otro estudio reportó que el aumento en los compuestos fenólicos se mostró con la aplicación de estimulantes durante el envero de la fruta (Jeong et al., 2004). Aunque el contexto no está claramente definido, se han propuesto mecanismos de acción del Se en el metabolismo vegetal. Uno de ellos es a través de la vía biosintética de compuestos orgánicos como el fenilpropanoide, que conduce a la acumulación de metabolitos secundarios (Zahedi et al., 2019).

Los flavonoides son compuestos bioactivos contenidos en todos los alimentos (Porras-Loaiza y López-Malo, 2009) y estos grupos de compuestos son especialmente relevantes en la calidad del vino (Valls et al., 2000). Su estructura les confiere una capacidad antioxidante, proporcionando protección contra el daño oxidativo en las células y también tiene un efecto positivo en una serie de patologías, incluyendo enfermedades cardíacas, aterosclerosis y cáncer (Martínez-Flórez et al., 2002). En cuanto al contenido total de flavonoides, un estudio revela que existe evidencia de un efecto de oligoelementos como el Se en la capacidad antioxidante de las plantas (Blasco et al., 2008). Para explicar este comportamiento, se han propuesto tres mecanismos de transporte sinérgicos en la biosíntesis de los flavonoides, el transporte mediado por el tráfico de vesículas, a través de transportadores de membrana, y el transporte mediado 
stress (Peralta-Pérez and VolkeSepúlveda, 2012). These compounds are classified according to their nature, and some mineral elements such as $\mathrm{Cu}, \mathrm{Zn}, \mathrm{Mn}, \mathrm{Fe}$ and Se act as cofactors in the production of antioxidant compounds (PorrasLoaiza and López-Malo, 2009); e.g. the enzyme Glutathione peroxidase, where Se is a structural part of each of the four catalytic centers (CasalsMercadal et al., 2005).

\section{Selenium concentration in fruits}

Selenium concentration in grapefruits increased linearly $\left(y=290.11 x-406.21 \quad R^{2}=0.9478\right) \quad$ as doses of Se increased (Figure 1D). The use of $1.25 \mathrm{mg} . \mathrm{L}^{-1}$ of Se favored an accumulation of his element in grape fruits. This accumulation is 12.72 times more than obtained in the lowest dose evaluated. The accumulation of Se in edible parts of some biofortified plant products has been reported in some studies with increases of about $30 \%$ in Se (Zhu et al., 2017). In general, the accumulation of Se through plant metabolic pathways, not only depends on the species to which the element is being applied, but also on the chemical compound used and the way in which it is supplied (Li et al., 2018).

Although Se is not an essential element for plant species, given its affinity for Sulfur, this element can replace inside the plant metabolism by Se, because it exists in the same oxidation states (Broadley et al., 2006), creating the hypothesis that it can fulfill biological functions of great benefit (Puccinelli et al., 2017a) and obtain an additional por la enzima glutatión-S-transferasa (GST) (Rousserie et al., 2019). Esta última, a su vez, utiliza un residuo de cisteína (Cys), que es un aminoácido en el que el Se puede sustituir al azufre, y formar selenocisteína (SeCys) (Casals-Mercadal et al., 2005). Otros estudios dirigidos a aumentar el contenidototal deflavonoides mediante la aplicación de micronutrientes han obtenido resultados favorables. Por ejemplo, un estudio informa de un aumento del $63 \%$ de los flavonoides totales en el ajo (Allium sativum L.) debido a la aplicación de Se (Shafiq et al., 2019).

La capacidad antioxidante de las frutas y vegetales está influenciada por el contenido fenólico total (Franco-Bañuelos et al., 2019). En esta investigación, se encontró una correlación positiva $(r=0.82)$ entre la capacidad antioxidante total y los compuestos fenólicos totales. Zahedi et al. (2019), reportan un aumento del $18,24 \%$ en la capacidad antioxidante en granada (Punica granatum) debido a la aplicación foliar de Se. De la misma manera, se reportó un aumento en la capacidad antioxidante de las semillas y plántulas de tomate cuando se aplicó Se por una solución nutritiva y por aspersión foliar (de los Santos-Vázquez et al., 2016). Las especies vegetales contienen una compleja red de defensa antioxidante, donde los compuestos más importantes son: ascorbato, glutatión, taninos, flavonoides y carotenoides, que proporcionan protección contra el estrés oxidativo (Peralta-Pérez y Volke-Sepúlveda, 2012). Estos compuestos se clasifican según su naturaleza, y algunos 
source of Se. Previous studies show that biofortification significantly increases the amount of essential elements in the edible part of plants (da Silva et al., 2020). This study has demonstrated the ability of grapevine to accumulate Se in the edible part, from the smallest dose applied to the one with the highest concentration, which leaves open the possibility of including this plant species for future biofortification programs. In addition, the accumulation obtained from $\mathrm{Se}$ in grape fruits could supplement the daily intake recommended by the USDA (Puccinelli et al., 2017b).

\section{Conclusions}

Grapes appear to be a good target for Se biofortification to increase human intake of this essential micronutrient without affecting performance and quality parameters. In addition, the biofortification increases the content of Se, total phenolic compounds, flavonoids, and greater antioxidant capacity of grapes, which translates into an improvement in the synthesis of antioxidant compounds and their nutraceutical quality. Selenium enrichment could play a critical role in triggering metabolic pathways leading to an increase in compounds beneficial to health in humans.

\section{End of English Version}

elementos minerales tales como $\mathrm{Cu}$, $\mathrm{Zn}, \mathrm{Mn}, \mathrm{Fe}$ y Se actúan como cofactores en la producción de compuestos antioxidantes (Porras-Loaiza y LópezMalo, 2009); por ejemplo, la enzima glutatión peroxidasa, donde el Se forma parte estructural de cada uno de los cuatro centros catalíticos (CasalsMercadal et al., 2005).

Concentración de selenio en los frutos

La concentración de selenio en las uvas aumentó linealmente $\left(y=290,11 x-406,21 \quad R^{2}=0,9478\right) \quad a$ medida que aumentaban las dosis de Se (Figura 1D). El uso de 1,25 mg.L ${ }^{1}$ de Se favoreció una acumulación de este elemento en los frutos de uva. Esta acumulación es 12,72 veces superior a la obtenida en la dosis más baja evaluada. La acumulación de Se en las partes comestibles de algunos productos vegetales biofortificados ha sido reportada en algunos estudios con aumentos de alrededor del $30 \%$ de Se (Zhu et al., 2017). En general, la acumulación de Se mediante las vías metabólicas de las plantas, no solo depende de las especies en las cuales el elemento es aplicado, sino también del compuesto químico utilizado y de la forma en la que se suministra (Li et al., 2018). Aunque el Se no es un elemento esencial para las especies vegetales, dada su afinidad por el Azufre, este elemento se puede sustituir dentro del metabolismo de la planta por el Se, ya que existe en los mismos estados de oxidación (Broadley et al., 2006), creando la hipótesis de que puede cumplir funciones biológicas de gran beneficio (Puccinelli et al., 2017a) y obtener una fuente adicional de Se. Estudios anteriores muestran que la biofortificación aumenta significativamente la cantidad de elementos esenciales en la parte comestible de las plantas (da Silva et 
al., 2020). Este estudio ha demostrado la capacidad de la vid para acumular Se en la parte comestible, desde la menor dosis aplicada hasta la de mayor concentración, lo que deja abierta la posibilidad de incluir esta especie vegetal para futuros programas de biofortificación. Además, la acumulación obtenida de Se en los frutos de la uva podría complementar la ingesta diaria recomendada por el USDA (Puccinelli et al., 2017b).

\section{Conclusion}

Las uvas parecen ser un buen objetivo para la biofortificación del Se con el fin de aumentar la ingesta humana de este micronutriente esencial sin afectar a los parámetros de rendimiento y calidad. Además, la biofortificación aumenta el contenido de Se, los compuestos fenólicos totales, los flavonoides y la mayor capacidad antioxidante de las uvas, lo que se traduce en una mejora de la síntesis de compuestos antioxidantes y de su calidad nutracéutica. El enriquecimiento con selenio podría desempeñar un papel fundamental en la activación de las vías metabólicas que conducen a un aumento de los compuestos beneficiosos para la salud en los seres humanos.

\section{Literature cited}

Association of Official Analytical Chemists (AOAC). 1990. Official Methods of Analysis, 15th Edition. Association of Official Analytical Chemists, Washington, DC.

Aviña de la Rosa, D. M. d. R., J. CarranzaTellez, B. A. Vázquez-Huirtrón and J. Carranza-Concha. 2016. Capacidad antioxidante y contenido fenólico de uva blanca (Vitis vinifera L.) sin semilla. Investigación y Desarrollo en Ciencia y Tecnología en Alimentos. 1(1): 801-805.

Blasco, B., J. Rios, L. Cervilla, E. Sánchez $\square$ Rodrigez, J. Ruiz and L. Romero. 2008. Iodine biofortification and antioxidant capacity of lettuce: potential benefits for cultivation and human health. Ann Appl Biol. 152(3): 289-299.

Bocchini, M., R. D'Amato, S. Ciancaleoni, M. Fontanella, C. A. Palmerini, G. M. Beone, A. Onofri, V. Negri, G. Marconi and E. Albertini. 2018. Soil selenium (Se) biofortification changes the physiological, biochemical and epigenetic responses to water stress in Zea mays L. by inducing a higher drought tolerance. Front. Plant Sci. $9 ; 389$.

Brand-Williams, W., M. Cuvelier and C. Berset. 1995. Use of a Free Radical Method to Evaluate Antioxidant Activity. LWT-Food Sci. Technol. 28(1): 25-30.

Broadley, M. R., P. J. White, R. J. Bryson, M. C. Meacham, H. C. Bowen, S. E. Johnson, M. J. Hawkesford, S. P. McGrath, F. J. Zhao and N. Breward. 2006. Biofortification of UK food crops with selenium. P Nutr. Soc. 65(2): 169-181.

Casals-Mercadal, G., M. TorraSantamaria, R. Deulofeu-Piquet and A. Ballesta-Gimeno. 2005. Importancia del selenio en la práctica clínica. Química Clínica. 24(3): 141-148.

da Silva, D. F., P. E. Cipriano, R. R. de Souza, M. S. Júnior, V. Faquin, M. L. de Souza Silva and L. R. G. Guilherme. 2020. Biofortification with selenium and implications in the absorption of macronutrients in Raphanus sativus L. J. Food Compos. Anal. 86: 103382.

de los Santos-Vázquez, M. E., A. BenavidesMendoza, N. A. Ruiz-Torres, M. Cabrera-de la Fuente and Á. Morelos-Moreno. 2016. Sodium selenite treatment of vegetable 
seeds and seedlings and the effect on antioxidant status. Emir J. Food Agr. 589-593.

Ducsay, L., O. Ložek, M. Marček, M. Varényiová, P. Hozlár and T. Lošák. 2016. Possibility of selenium biofortification of winter wheat grain. Plant Soil Environ. 62(8): 379-383.

Franco-Bañuelos, A., S. HernándezTrujillo, C. S. Contreras-Martínez, J. Carranza-Téllez and J. CarranzaConcha. 2019. Use of growth regulators on the total phenolic content and the antioxidant capacity of "red globe" grape. Agrociencia. 53(6): 881-894.

Garcia-Nava, M. A. 2009. Cuantificación de fenoles y flavonoides totales en extractos naturales. Universidad Autónoma de Querétaro Revista Academica 1: 1-4.

Garduño-Zepeda, A. and C. MárquezQuiroz. 2018. Aplicación de selenio en cultivos agrícolas. Revisión bibliográfica. ITEA. informacion técnica económica agraria: revista de la Asociación Interprofesional para el Desarrollo Agrario. 114(4): 327-343.

Gaucín-Delgado, J. M., L. G. HernándezMontiel, E. Sánchez-Chávez, H. Ortega-Ortiz, M. FortisHernández, J. J. Reyes-Pérez and P. Preciado-Rangel. 2020. Agronomic biofortification with selenium improves the yield and nutraceutical quality in tomato under soilless conditions. Not. Bot. Horti. Agrobot. 48(3): 1221-1232.

Hernández-Hernández, H., T. QuiterioGutiérrez, G. Cadenas-Pliego, H. Ortega-Ortiz A. D. HernándezFuentes, M. Cabrera de la Fuente, J. Valdés-Reyna and A. JuárezMaldonado. 2019. Impact of selenium and copper nanoparticles on yield, antioxidant system, and fruit quality of tomato plants. Plants. 8(10): 355.

Jeong, S. T., N. Goto-Yamamoto, S. Kobayashi and M. J. P. S. Esaka. 2004. Effects of plant hormones and shading on the accumulation of anthocyanins and the expression of anthocyanin biosynthetic genes in grape berry skins. Plant Sci. 167(2): $247-252$

Kápolna, E., P. R. Hillestrøm, K. H. Laursen, S. Husted and E. H. Larsen. 2009. Effect of foliar application of selenium on its uptake and speciation in carrot. Food Chem. 115(4): 1357-1363.

Kuldeep, V., A. Yadav, H. Singh and D. Yadav. 2010. Effect of foliar spray of nutrients on fruit drop, yield and quality attributes of mango fruit (Mangifera indica L.) cv-Amrapali. Plant Arch. 10: 359-360.

Lapaz, A. d. M., L. F. d. M. Santos, C. H. P. Yoshida, R. Heinrichs, M. Campos and A. R. D. Reis. 2019. Physiological and toxic effects of selenium on seed germination of cowpea seedlings. Bragantia. 78(4) :498-508.

Li, M., Z. Zhao, J. Zhou, D. Zhou, B. Chen, L. Huang, Z. Zhang and X. Liu. 2018. Effects of a foliar spray of selenite or selenate at different growth stages on selenium distribution and quality of blueberries. Journal of the Science of Food and Agriculture, 98(12), 47004706. https://doi.org/10.1002/jsfa.9004

Lyons, G., I. Ortiz-Monasterio, J. Stangoulis and R. Graham. 2005. Selenium concentration in wheat grain: is there sufficient genotypic variation to use in breeding?. Plant Soil. 269(1-2): 369-380.

Malagoli, M., M. Schiavon, S. Dall'Acqua and E. A. Pilon-Smits. 2015. Effects of selenium biofortification on crop nutritional quality. Front. Plant Sci. 6: 280.

Martínez-Flórez, S., J. González-Gallego, J. M. Culebras and M. J. Tuñón. 2002. Los flavonoides: propiedades y acciones antioxidantes. Nutrición Hospitalaria. 17(6): 271-278.

Mimmo, T., R. Tiziani, F. Valentinuzzi, L. Lucini, C. Nicoletto, P. Sambo, M. Scampicchio, Y. Pii and S. Cesco. 2017. Selenium Biofortification in Fragaria x ananassa: Implications on Strawberry Fruits Quality, Content of Bioactive Health Beneficial Compounds and Metabolomic Profile. Front Plant Sci. 8: 1887. 
Molina-Quijada, D., L. Medina-Juárez, G. González-Aguilar, R. RoblesSánchez and N. Gámez-Meza. 2010. Compuestos fenólicos y actividad antioxidante de cáscara de uva (Vitis vinifera L.) de mesa cultivada en el noroeste de México. Phenolic compounds and antioxidant activity of table grape (Vitis vinifera L.) skin from northwest Mexico. CyTA-J Food. 8(1): 57-63.

Mora, M., P. Durán, J. Acuña, P. Cartes, R. Demanet and L. Gianfreda. 2015. Improving selenium status in plant nutrition and quality. Journal of Soil Science Plant Nutrition. 15(2): 486-503.

Oliveira, V. C. d., V. Faquin, K. C. Guimarães, F. R. Andrade, J. Pereira and L. R. G. Guilherme. 2018. Agronomic biofortification of carrot with selenium. Ciência e Agrotecnologia. 42(2), 138-147. https://doi.org/10.1590/141370542018422031217

Peralta-Pérez, M. d. R. and T. VolkeSepúlveda. 2012. La defensa antioxidante en las plantas: una herramienta clave para la fitorremediación. Rev Mex Ing Quim. 11(1): 75-88.

Ponavic, M. and A. Scheib. 2014. Distribution of Selenium in European Agricultural and Grazing Land Soil. pp. 131-144. In "Chemistry of Europe's Agricultural Soils" (C. Reimann, M. Birke, A. Demetriades, P. Filzmoser and P. O'Connor, eds.), vol. 103.

Porras-Loaiza, A. and A. López-Malo. 2009. Importancia de los grupos fenólicos en los alimentos. Temas Selectos de Ingeniería de Alimentos. 3(1): 121134.

Puccinelli, M., F. Malorgio and B. Pezzarossa. 2017a. Selenium Enrichment of Horticultural Crops. Molcules. 22: 933.

Puccinelli, M., F. Malorgio, I. Rosellini and B. Pezzarossa. 2017b. Uptake and partitioning of selenium in basil (Ocimum basilicum L.) plants grown in hydroponics. Sci Hortic. 225: 271-276.
Rousserie, P., A. I. Rabot and L. Geny-Denis. 2019. From Flavanols Biosynthesis to Wine Tannins: What Place for Grape Seeds?. J. Agric. Food Chem. 67(5): 1325-1343.

Ruffner, H. 1982. Metabolism of tartaric and malic acids in Vitis: A review-Part B. Vitis. 21: 346-358.

Schiavon, M., S. Dall'acqua, A. Mietto, E. A. Pilon-Smits, P. Sambo, A. Masi and M. Malagoli. 2013. Selenium fertilization alters the chemical composition and antioxidant constituents of tomato (Solanum lycopersicon L.). J. Agric. Food Chem. 61(44): 10542-10554.

Shafiq, M., A. Qadir and S. Ahmad. 2019. Biofortification: A Sustainable Agronomic Strategy to Increase Selenium Content and Antioxidant Activity in garlic. Appl Ecol Env Res. 17(2): 1685-1704.

Silva-Trejos, P. 2011. Validación de la metodología analítica para cuantificación de Selenio en alimentos de la canasta básica del costarricense. Revista Costarricense de Salud Pública. 20(1): 31-35.

StatSoft Inc. 2011. Statistica. System reference. StatSoft, Inc., Tulsa, Oklahoma, EUA.

Valls, J., M. Lampreave, M. Nadal and L. Arola. 2000. Importacia de los compuestos fenolicos en la calidad de los vinos tintos de crianza. Alimentacion Equipos y Technologia. 19(2): 119-124.

Walteros, I., D. Molano, P. J. Almanza, M. Camacho and S. Gónzalez Almanza. 2012. Effect of pruning on chemical changes during fruit ripening of Vitis vinifera L. var. Cabernet Sauvig. Cultura Cientifica. 10: 8-15.

Weaver, R. 1985. "Cultivo de Uva". Segunda Impresión. Editorial Continental, México.

Willers, J., M. Heinemann, N. Bitterlich and A. Hahn. 2015. Intake of minerals from food supplements in a German population-a nationwide survey. Food Nutrition Sciences, 6(2), 205-215. https://doi.org/10.4236/ fns.2015.62021 
Rev. Fac. Agron. (LUZ). 2021, 38(4):806-824. Octubre-Diciembre.

Sariñana-Navarrete et al.

ISSN 2477-9407

World Health Organization (WHO). 2009.

Global Health Risks: Mortality and Burden of Disease Attribut-Ableto Selected Major Risks. Retrieved March 5 from http://www.who.int/ healthinfo/global_burden_disease/ GlobalHealthRisks_report_annex.pdf

Wu, Z., G. S. Bañuelos, Z.-Q. Lin, Y. Liu, L. Yuan, X. Yin and M. Li. 2015. Biofortification and phytoremediation of selenium in China. Front. Plant Sci. 6: 1-8.

Zahedi, S. M., M. S. Hosseini, N. D. H. Meybodi and J. A. T. da Silva. 2019. Foliar application of selenium and nano-selenium affects pomegranate (Punica granatum cv. Malase Saveh) fruit yield and quality. S. Afr. J. Bot. 124: 350-358.
Zhao, H., J. Huang, Y. Li, X. Song, J. Luo, Z. Yu and D. Ni. 2016. Natural variation of selenium concentration in diverse tea plant (Camellia sinensis) accessions at seedling stage. Sci. Hortic. 198: 163-169.

Zhu, S., Y. Liang, X. An, F. Kong, D. Gao and H. Yin. 2017. Changes in sugar content and related enzyme activities in table grape (Vitis vinifera L.) in response to foliar selenium fertilizer. J. Sci. Food Agric. 97: 4094-4102. 